\title{
Simulation of Atmospheric Humidity Uptake by the Aerial Roots of Plants
}

\author{
Médéhouénou Enagnon Alexis ${ }^{1,2, *}$, Kounouhéwa Bruno Basile ${ }^{1,2}$, Kouchadé Clément ${ }^{1}$ \\ ${ }^{1}$ Laboratory of Radiation Physics, University of Abomey Calavi, Abomey Calavi, Bénin \\ ${ }^{2}$ Beninese Center for Scientific Research and Innovation, Ministry of Higher Education and Scientific Research, Cotonou, Bénin
}

Email address:

medehouenou@yahoo.fr (M. E. Alexis),kkbasile@gmail.com (K. B. Basile), ckouchade@yahoo.fr (K. Clément)

*Corresponding author

\section{To cite this article:}

Médéhouénou Enagnon Alexis, Kounouhéwa Bruno Basile, Kouchadé Clément. Simulation of Atmospheric Humidity Uptake by the Aerial Roots of Plants. Plant. Vol. 5, No. 6, 2017, pp. 104-109. doi: 10.11648/j.plant.20170506.14

Received: August 14, 2017; Accepted: August 31, 2017; Published: December 22, 2017

\begin{abstract}
The mobilization of water by the plant is one of the main challenges of the moment given the threats of food insecurity whose main cause is climate change. The atmosphere contains moisture at any time of the year in the arid or semiarid zone. Apart from the underground roots naturally possessed by many plants, there are plants which possess exclusively or not aerial roots. In the search for methods of adapting crops to water stress, it is imperative to deepen knowledge about interaction between atmospheric humidity and the aerial roots of plants with respect to water absorption. Assuming transfer coefficients of the aerial roots homogeneous and taking into account the variability of the water potential of atmospheric humidity, simulations showed that relative air humidity, root size, and radial and axial transfer coefficients strongly influence radial and axial flows and therefore the amount of water absorbed by the roots.
\end{abstract}

Keywords: Water Stress, Aerial Roots, Air Humidity, Water Potential

\section{Introduction}

Climate change has already left its mark "on all continents and across the oceans", damaging food crops, spreading disease, and melting glaciers [1]. Africa is one of the most vulnerable regions in the world in terms of climate change. Some of its physical and socio-economic characteristics, including the fragility of its economy, predispose it to be affected disproportionately by the adverse effects of climate change [2].

One of climate change manifestation is the drop in precipitation and an increase in the frequency of extreme events (random succession of very dry years and very rainy years). The consequences of these climatic hazards are among others drought that seriously affects agricultural yields, leading to major crises. In this regard, 2011 is an edifying example. During this year, the UN is alerting the international community to the plight of Somalia, Ethiopia and Kenya, where an episode of drought unparalleled since 60 years has caused a major food crisis with over 12 million people affected by famine.
The West African climate had changed greatly during the last century, particularly in terms of rainfall, and these climatic hazards played an important role on the agricultural yields [3]. Faced with the pronounced climatic variations that West Africa has known since the 1970s, Adaptation methods have emerged as the only alternative to reducing the vulnerability of rural populations [4].

Plants develop natural adaptation mechanisms: This form of adaptation is possible thanks to the internal mechanisms of root growth, water absorption and reduction of water losses (Hydro-active closure of stomata during periods of water deficiency). Also, there are adaptive methods linked to agricultural practices: for example, in the west of the Central African Republic, farmers have deliberately adopted practices in order to reduce the effects of climatic hazards, Among these practices, these include early seeding and the use of short-cycle varieties that allow the crop cycle to best coincide with the rainy season and thus reduce the period of water stress at the end of cycle [5].

All these measures will only be effective if the seasonal forecast is mastered. The seasonal prediction is made by the climate models; it can be subject to great uncertainties [6]. 
Atmosphere abounds millions of cubic kilometers of water in the form of condensable steam, and thus constitutes an inexhaustible reservoir of water resources, valued in several arid or semi-arid countries [7]. In the search for a solution to the water stress experienced by crop plants because of climatic change, it is essential to make the plants to benefit from the humidity of the air.

The condensed humidity (dew) can allow corn to finish its cycle in times of water stress [8]. However it constitutes for the plant a random resource because the dew formation depend on the conditions namely a clear sky, absence of the wind.

Some plants such as Orchidaceae, Morgeniusae, Araceae, Liliaceae, Amaryllidaceae have aerial roots [9-11]. In 1940 Went assumed that the velamen, which is a spongy tissue surrounding the roots, has as its principal function the capture of atmospheric water [12]. Zotz and Winkler verified and supported Went hypothesis from a series of experiments on epiphytic orchids [13].

Some scientists have thought that aerial root velamen is an absorption tissue such as spongy or active carbon [14-15]. Liu and al in their work on the absorption of air moisture by the aerial roots of Ficus microcarpa (L) proved that velamen absorbs moisture from the air like spongy or active carbon [16].

Water uptake by plants underground roots has been the subject of several studies [17-35]. These works, taking into account mainly the relationships between roots and soil water, have shown that the motor responsible of water uptake by the roots is the gradient of the water potential.

In the current context of climatic change where plants are subject to water stress and since the atmosphere is filled with millions of cubic kilometers of water in the form of condensable vapor it is necessary to deepen our understanding of the interactions between Atmospheric moisture and aerial roots of plants. The results of the various simulations will help motivate geneticists, biologists to consider the development of crop plants that can uptake air humidity by aerial roots which will complement the water they naturally pulls from the ground to mitigate water stress in dry periods.

\section{Mathematical Model}

\subsection{Radial Transfer}

According to Fiscus [31]; the radial flow of water through the root is given by:

$$
j_{r}=k_{r}(\Delta P-\sigma \Delta \Pi)
$$

The reflection coefficient $\sigma$ takes values between 0 and 1 and is an indication of the efficiency of the complex membrane. For a well developed endoderm therefore a perfect semi-permeable membrane, $\sigma=1$.

$$
\Psi_{r}=P_{r}+\Pi_{r} \text { and } \Psi_{s}=P+\Pi
$$

Relation 1 becomes:

$$
j_{r}=-k_{r}\left(\Psi_{r}-\Psi_{s}\right)
$$

\subsection{Axial Transfer}

Water flows axially from the root and along the xylem vessels. According to the law of Poiseuille, the axial flow of water is:

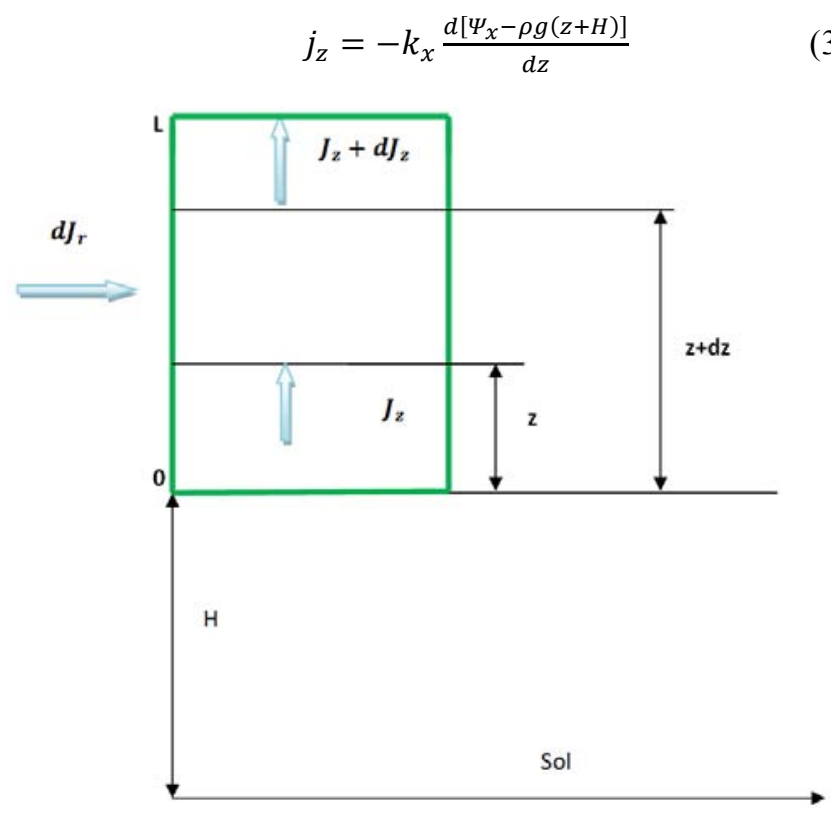

Figure 1. Physical model of an aerial root segment.

\subsection{Water Potential $\Psi_{s}$ of Water Vapor in the Atmosphere}

Determine the water potential of one mole of water vapor at pressure $p$, is to determining the energy necessary to bring it to the reference state, that is to say in equilibrium with pure water at the same temperature, in other words the steam at saturated pressure $P_{S}(T)$.

By assimilating the water vapor to a perfect gas obeying the law of Mariotte, The molar volume $\mathrm{V}$ at the pressure $\mathrm{p}$ and the temperature $\mathrm{T}$ is written:

$$
V=\frac{R T}{P}
$$

The reversible transformation which makes it possible to pass from the initial state $(\mathrm{P}, \mathrm{V})$ to the final state $\left(P_{S}(T), V_{S}(T)\right)$ is isothermal compression. During this compression, an elementary increase in pressure dp leads to a decrease in volume $\mathrm{dV}$ and requires an energy input $\mathrm{dW}$ :

$$
d W=R T \frac{d P}{P}
$$

The energy required to pass from $\mathrm{P}$ to $P_{S}(T)$ is obtained by integration:

$$
W=R T \int_{P}^{P_{S}(T)} \frac{d P}{P}=R T \ln \frac{P_{S}(T)}{P}
$$

It is this quantity of energy lost by water vapor when it is at the pressure $\mathrm{P}$ with respect to the saturating pressure, which intervenes in the calculation of the water potential of water vapor. 
Equation 6 shows that measuring the water potential in the air amounts to measuring the relative humidity $\mathrm{RH}$.

Conventionally, in order to express the water potential $\Psi_{S}$ in the gas phase, the energy quantity $\mathrm{W}$ thus calculated is reported to the molar volume of the liquid water $\mathrm{V}$.

$$
\Psi_{S}=\frac{R T}{V} \ln \frac{H R}{100}
$$

This relationship is used by Lucot and al [35].

\subsection{Water Potential $\Psi_{x}$ of Xylem}

Considering a surface element of the root and thus an element of length $\mathrm{dz}$, the radial flux and the axial flux become respectively:

$$
\begin{gathered}
d j_{r}=-2 \pi a d z k_{r}\left(\Psi_{x}-\Psi_{s}\right) \\
d j_{z}=-k_{x} \frac{d^{2} \Psi_{x}}{d z^{2}}
\end{gathered}
$$

According to the conservation of flux:

$$
-k_{x} \frac{d^{2} \Psi_{x}}{d z^{2}}=-2 \pi a k_{r}\left(\Psi_{x}-\Psi_{s}\right)
$$

Equation 10 becomes:

$$
\frac{d^{2} \Psi_{x}}{d z^{2}}=k^{2}\left(\Psi_{x}-\Psi_{S}\right)
$$

With:

$$
\mathrm{k}^{2}=\frac{2 \pi \mathrm{k}_{\mathrm{r}}}{\mathrm{k}_{\mathrm{x}}}
$$

boundaries conditions:

$$
\begin{aligned}
& \Psi_{x}=\Psi_{x l} ; z=L \\
& \frac{d \Psi_{x}}{d z}=0 ; z=0
\end{aligned}
$$

The resolution of Equation 6 gives:

$$
\Psi_{x}(z)=\Psi_{s}+\left[\Psi_{x l}-\Psi_{s}\right] \frac{\operatorname{Cosh}(k z)}{\operatorname{Cosh}(k L)}
$$

Which is the analytical solution firstly found by Landsberg and Fowkes for homogeneous radial conductivity and axial conductance $\left(k_{r}=k_{r 0} ; k_{x}=k_{x 0}\right)$ [29].

Relations 7 and 13 give:

$$
\Psi_{x}(z)=\frac{R T}{V} \ln \frac{H R}{100}+\left[\Psi_{x l}-\frac{R T}{V} \ln \frac{H R}{100}\right] \frac{\operatorname{Cosh}(k z)}{\operatorname{Cosh}(k L)}
$$

\subsection{Water Flow Through the Root}

The replacement of $\mathrm{k}$ by its expression gives:

$$
J_{r}(z)=-\left[\Psi_{x l}-\frac{R T}{V} \ln \frac{H R}{100}\right] \frac{k_{r 0} \operatorname{Cosh}\left(\sqrt{\frac{2 \pi a k_{r 0}}{k_{x 0}}} z\right)}{\operatorname{Cosh}\left(\sqrt{\frac{2 \pi a k_{r 0}}{k_{x 0}}} L\right)}
$$

$$
J_{x}(z)=-\left[\Psi_{r l}-\frac{R T}{V} \ln \frac{H R}{100}\right] \frac{\sqrt{2 \pi a k_{r 0} k_{x 0}} \sinh \left(\sqrt{\frac{2 \pi a k_{r 0}}{k_{x 0}}} z\right)}{\operatorname{Cosh}\left(\sqrt{\frac{2 \pi a k_{r 0} 0}{k_{x 0}}} L\right)}+\rho g k_{x 0}
$$

With $j_{z}=j_{x}$.

Table 1. Numerical values using.

\begin{tabular}{llll}
\hline $\begin{array}{l}\text { radius } \mathbf{r} \\
(\mathbf{m})\end{array}$ & $\begin{array}{l}\boldsymbol{k}_{\boldsymbol{r} \mathbf{0}} \\
\left(\mathbf{m s}^{-\mathbf{1}} \boldsymbol{M} \boldsymbol{P a ^ { - 1 }}\right)\end{array}$ & $\begin{array}{l}\boldsymbol{k}_{\boldsymbol{x} \mathbf{0}} \\
\left(\mathbf{m s}^{-\mathbf{4}} \boldsymbol{M} \boldsymbol{P a}^{-\mathbf{1}}\right)\end{array}$ & Reference \\
\hline $510^{-4}$ & $2.510^{-7}$ & $10^{-9}$ & $\begin{array}{l}\text { Frensch and al } \\
(1989)\end{array}$ \\
$310^{-3}$ & $210^{-7}$ & $510^{-11}$ & $\begin{array}{l}\text { Huang and Nobel } \\
(1994) .\end{array}$ \\
\hline
\end{tabular}

\section{Results and Discussion}

Water potential of atmospheric water vapor depends on the temperature and relative humidity of the air. Figure 1 shows that the water vapor potential of water contained in the air varies from $-18.10^{7} \mathrm{~Pa}$ to $0 \mathrm{~Pa}$ for the temperature and humidity ranges considered. The relative humidity of the air has a strong influence on the water vapor potential of water contrariwise; the temperature of the air influences it very little.

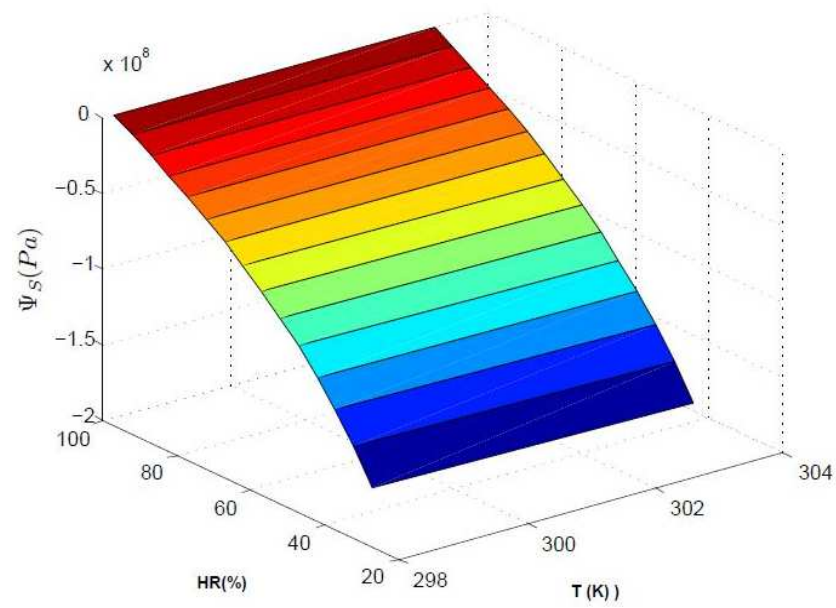

Figure 2. Evolution of the water vapor potential in air.

The graphs a, b, c and d of figure 3 obtained with the axial conductivity and radial conductivity values found by Huang and Nobel [32]; Frensh and Steudle [24] for maize, show that the plant cannot absorb water for the values of respective base water potentials $-10^{7} \mathrm{~Pa},-10^{6} \mathrm{~Pa}$ and $-10^{5} \mathrm{~Pa} \mathrm{~Pa}$ because the curves representative of water potentials of the xylem are above that of water vapor. On the other hand, for the basic water potential equal to $-10^{8} \mathrm{~Pa}$, root absorption is initiated from $60 \%$ relative humidity for the transfer coefficient values found by Huang and Nobel; Frensh and Steudle. However, this absorption is strongly influenced by the radial and axial transfer coefficients of the root.

When the relative humidity is less than $60 \%$, the plant tends to lose water; since the aerial roots are covered with a spongy tissue called velamen, whose one of the roles is to limit the loss of water [13]; the loss cannot therefore take place. 

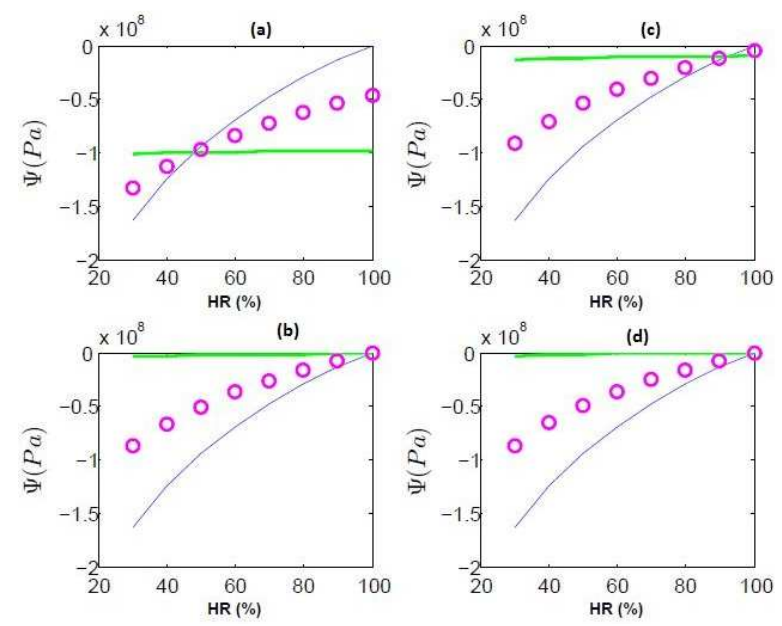

Figure 3. Influence of the radial conductivity coefficients, the axial conductance and the water potential at the base on the xylem water potential evolution.

In blue the curve of the water vapor potential; in green the curve of the water potential of the xylem with the values of Frensch and Steudle [24]. In pink circles the curve of the water potential of the xylem with the data of Huang and Nobel [32]. $z=0,02 \mathrm{~m} ; \mathrm{L}=0,03 \mathrm{~m}$.

The graphs of figure 4 obtained with the base water potential $-10^{8} \mathrm{~Pa}$ for temperatures between $293.16 \mathrm{~K}$ and $308.16 \mathrm{~K}$ show that the water potential of the xylem remains almost constant, which proves that the temperature of air influences very little the water potential of xylem.
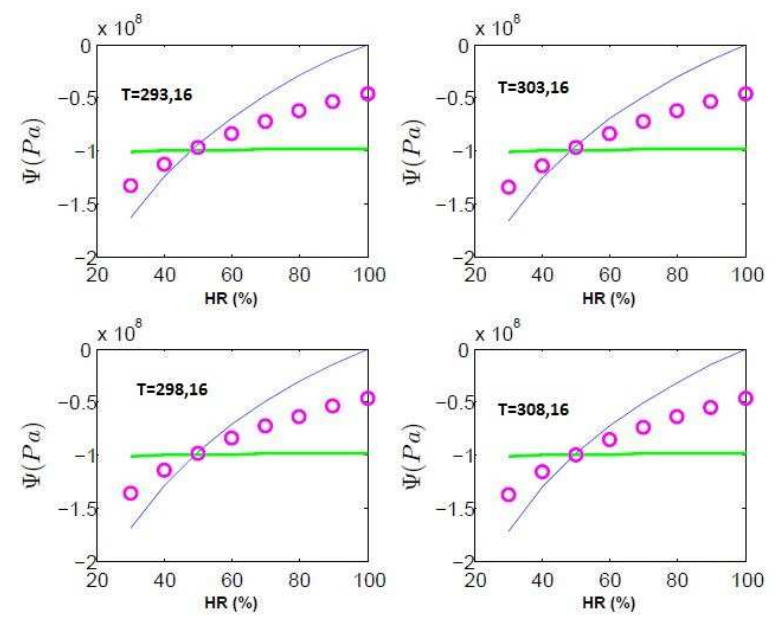

Figure 4. Influence of temperature on the evolution of water potentials.

In blue the curve of water vapor potential; in green the xylem water potential curve with the values of Frensch and Steudle [24]. In pink circles the curve of the water potential of the xylem with the data of Huang and Nobel [32]. $\Psi_{r l}=-10^{8} \mathrm{~Pa} . \mathrm{z}=20 \mathrm{Cm} ; \mathrm{L}=30 \mathrm{Cm}$

The graphs of figure 5 show that for different relative humidity values of the air, the water potential of the xylem decreases as a function of the size of the root. The closer we get to the base of the root the lower the water potential.

The graphs of figure 6 show that the radial flow of water is almost constant for different relative humidity values of the air with the values of transfer coefficients found by Frensch and Steudle following to the size of the root. As to the Huang and Nobel values, the radial flux increases significantly following to relative humidity values and root size, but remains lower than that resulting from the values of Frensch and Steudle.

The graphs of Figure 7 show that the axial flow of water increases slightly for different relative humidity values of the air with the values found by Frensch and Steudle following the size of the root. As to the Huang and Nobel values, the axial flux increases significantly according to relative humidity values and root size, but remains higher than that resulting from the values of Frensch and Steudle.

The size of the root is therefore determining as regards the amount of moisture of the air that the root can uptake; This is explained by the fact that the whole root is in contact with the humidity of the air via the surface of exchange that constitutes the velamen which is a true trap to the humidity of the air.
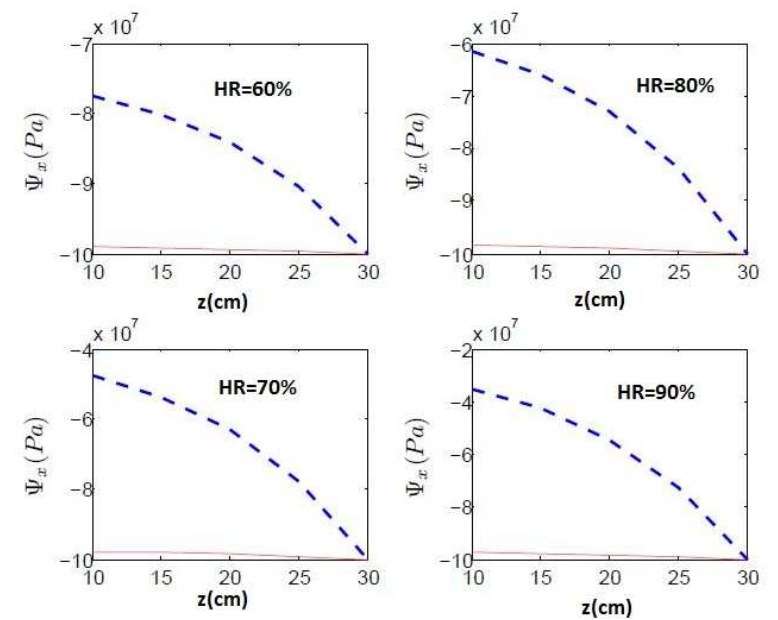

Figure 5. Evolution of the water potential of the xylem following the length of the root segment.

In red the curve of the water potential of the xylem with the values of Frensch and Steudle [24]. In blue dashes the curve of the water potential of the xylem with the data of Huang and Nobel [32]. $\Psi_{r l}=-10^{8} \mathrm{~Pa} ; \mathrm{L}=30 \mathrm{Cm}$.
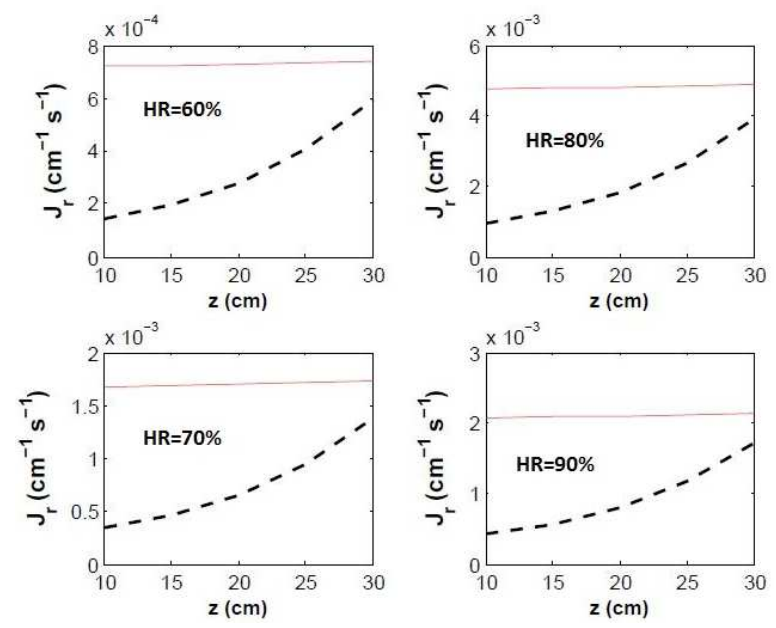

Figure 6. Evolution of the radial flow of water following the length of the root segment. 
In red the water potential of the xylem with the values of Frensch and Steudle [24]. In black dashes the water potential of the xylem with data from Huang and Nobel [32]. $\Psi_{r l}=$ $-10^{8} \mathrm{~Pa} ; \mathrm{L}=30 \mathrm{Cm}$.
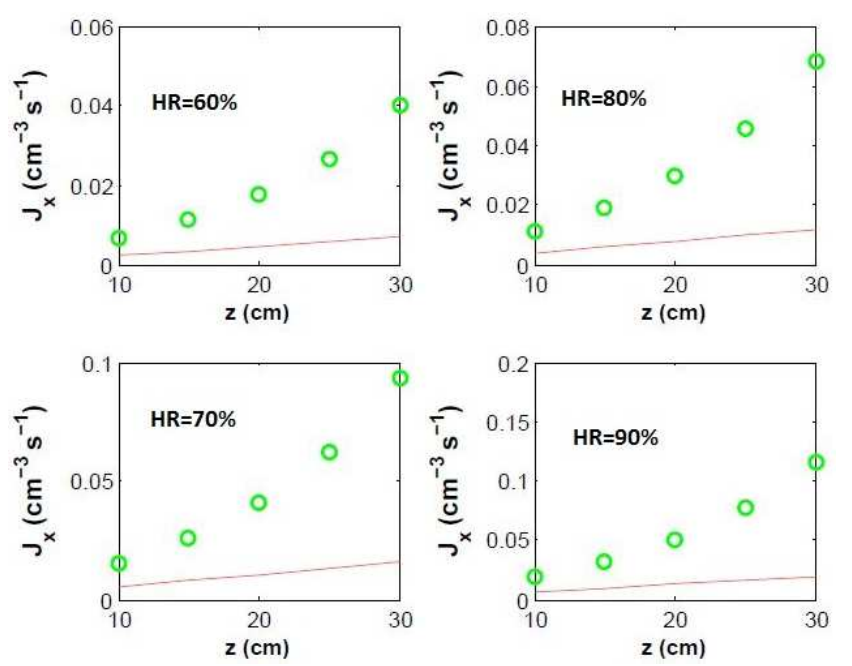

Figure 7. In red the curve of the water potential of the xylem with the values of Frensch and Steudle [24]. In green circles the curve of the water potential of the xylem with the data of Huang and Nobel [32]. $\Psi_{r l}=-10^{8} ; L=30$ $\mathrm{Cm}$.

\section{Conclusion}

Simulations show that the aerial roots of plants absorb moisture from the air. This absorption depends on several parameters, including relative air humidity, radial root conductivity, axial root conductance and root size. The larger the root, the more it offers a large area of exchange to the atmosphere. For the considered values, absorption is started from a relative humidity threshold of $60 \%$ Temperature has little effect on root absorption because it does not substantially affect water vapor and xylem water potentials.

\section{References}

[1] IPCC report: climate change felt 'on all continents and across the oceans 2014.

[2] M. Niasse, A. Afouda, A. Amani, Réduire la vulnérabilité de l'Afrique de l'Ouest aux impacts du climat sur les ressources en eau, les zones humides et la désertification. Eléments de stratégie régionale de préparation, UICN, Gland (Switzerland) et Cambridge (UK) (eds), série 5, 2004.

[3] P. Roudier, B. Sultan, P. Quirion, A. Berg, The impact of future climate change on West African crop yields: what does the recent literature say? Global Environmental Change, 21, 2011a, 1073-1083.

[4] M. A. Tidjani, P. B. I. Akponikpe. Evaluation des stratégies paysannes d'adaptation aux changements climatiques: cas de la production du maïs au nord-bénin. African Crop Science Journal, Vol. 20, Issue Supplements 2, 2012, pp. 425-441.

[5] B. Doukpolo, Changements climatiques et productions agricoles dans l'Ouest de la République Centrafricaine, Thèse de Doctorat, Université d'Abomey-Calavi, Bénin 2014.
[6] P. Roudier, Climat et agriculture en Afrique de l'Ouest: Quantification de l'impact du changement climatique sur les rendements et évaluation de l'utilité des prévisions saisonnières; Thèse de doctorat, EHESS, Paris, 2012.

[7] O. Clus, Condenseur radiatif de la vapeur d'eau (rosée) comme source alternative d'eau, Thèse de Doctorat, Université de Corse, 2007.

[8] G. Koto N'gobi, Humidite atmospherique condensable au bénin: contribution a la correction du stress hydrique chez le maïs en milieu semi-aride. Thèse de Doctorat de Université d'Abomey-Calavi, Bénin, 2014.

[9] B. Huggett, Aspects of vessel dimensions in the aerial roots of epiphytic araceae. Int. J. Plant Sci., 171(4), 2010, 362-369.

[10] C. R. Deb, A. Pongener. Studies on the in vitro regenerative competence of aerial roots of two horticultural important Cymbidium species. J. Plant Biochem. Biotechnol, 21(2), 2010, 235-241.

[11] S. M. Saifullah, S. Gul, F. Rasool, Anomalous aerial roots in grey mangroves of an arid climate lagoon. Pak. J. Bot., 36(2), 2004, 463-466.

[12] F. W. Went, Soziologie der Epiphyten eines tropischen Regenwaldes. Ann. Jard. Bot. Buitenzorg, 50, 1940, 1-98.

[13] G. Zotz, U. Winkler. Aerial roots of epiphytic orchids: the Velamen radicum and its role in water and nutrient uptake. Oecologia, 171, 2013, 733-741.

[14] J. M. Schleiden, L. Edwin. Principles of Botany. Green \& Longman, London Brown, 1849.

[15] G. Haberlandt, G. D. Montagu. Physiological Plant Anatomy, $4^{\text {th }}$ ed. Macmillan \& Co., London. 1914.

[16] L. Liu, X. Fu, X. Chen, The transpiration and moisture absorption characteristics of ficusmicrocarpa (1.) aerial roots in the south of china. Pak. J. Bot, 48(4), 2016, 1473- 1479.

[17] Meunier Félicien, Couvreur Valentin, Draye Xavier, Vanderborght Jan, Javaux Mathieu, Water movement through plant roots, Hydrol. Earth Syst. Sci. Discuss, 633, 2016.

[18] Claude Doussan, Alain Pierret, Emmanuelle Garrigues, Lo1c Pagès. Water uptake by plant roots: II - Modelling of water transfer in the soil root-system with explicit account of flow within the root system -Comparison with experiments. Plant and Soil 283, 2006, 99-117.

[19] Tiina Roose, Andrea Schnepf. Mathematical models of plantsoil interaction Phil. Trans. R. Soc. A, 366, 2008, 4597-4611.

[20] Anke Hildebrandt, Axel Kleidon, and Marcel Bechmann. A thermodynamic formulation of root water uptake Hydrol. Earth Syst. Sci, 20, 2016, 3441-3454.

[21] Ernst Steudle and Carol A. Peterson. How does water get through roots? Journal of Experimental Botany, Vol. 49, No. 322, 1998, pp. 775-788.

[22] G. T. Varney, M. J. Canny. Rates of water uptake into the mature root system of maize plants. Neiv Phytol, 123, 1993, 775-786.

[23] Claude Doussan., Loïc Pages, Gilles Vercambre, Modelling of the Hydraulic Architecture of Root Systems: An Integrated Approach to Water Absorption Model Description Annals of Botany 81, 1998, 213 \pm 223 . 
[24] Jurgen Frensch, Ernst Steudle. Axial and Radial Hydraulic Resistance to Roots of Maize (Zea mays L.) Plant Physiol, 91, $1989,719-726$.

[25] Mohsen Zarebanadkouki, Félicien Meunier, Valentin Couvreur, Jimenez Cesar, Mathieu Javaux and Andrea Carminati. Estimation of the hydraulic conductivities of lupine roots by inverse modeling of high-resolution measurements of root water uptake. Annals of Botany Page 1 of 12.

[26] R. Philip, Plant Water Relations: Some Physical Aspects Annu. Rev. Plant. Physiol, 17, 1966, 245-268.

[27] J. B. Passioura. Water Transport in and to Roots, Annu. Rev. Plant. Physiol. Plant. Mol. Biol, 39, 1988, 245-265.

[28] F. J. Molz. Modelsoion of Water Transport in the Soil-Plant System. Water Resources Research, Vol. 17, No 5, 1981, $1245-1260$.

[29] J. J. Landsberg. Water Movement Through Plant Roots Ann. Bot. 42, 493-508, 1978.
[30] P. A. C. Raats. Uptake of water from soils by plant roots. Transp Porous Med, 68, 2007, 5-28.

[31] Fiscus EL, The interaction between osmotic and pressure induced flow. Plant Physiology, 55, 1975, 917 1922 .

[32] B. Huang, P. S. Nobel, Root hydraulic conductivity and its components with emphasis on desert succulents. Agronomy Journal, 86, $1994767 \pm 774$.

[33] G. Lobet, V. Couvreur, F. Meunier, M. Javaux, X. Draye, Plant Water Uptake in Drying Soils, Plant Physiology, Vol. 164, April 2014, pp. 1619-1627.

[34] P. Tournier, Absorption de l'eau et des nutriments par les racines des plantes: Modélisation, analyse et simulation, Thèse de Doctorat, 1'Université Pierre et Marie Curie, 2015.

[35] E. Lucot, PM Badot, S. Bruckert. Influence de l'humidité du sol et de la distribution des raciness sur le potential hydrique du xylème dans le peuplement de chêne (Quercus sp) de basse altitude. Ann Sci for, Vol 52, 1995, 173-182. 